\title{
Elements to consider the video game as a support tool in the university classroom
}

\section{Elementos para considerar el videojuego como herramienta de apoyo en el aula universitaria}

GONZÁLEZ-NERI, Aarón Iván†, PÉREZ-BRAVO, Julia, ARELLANO-ROCHA, Francisco Javier and VILLARREAL-ALCALDE, Jorge Gabriel

Universidad Autónoma de Querétaro, Cerro de las Campanas S/N, Centro Universitario, Querétaro, Qro. C.P. 76010.

ID $1^{\text {st }}$ Author: Aarón Iván, González-Neri / ORC ID: 0000-0002-4082-0746, Researcher ID Thomson: X-3196-2018, CVU CONACYT ID: 503735

ID $1^{\text {st }}$ Coauthor: Julia, Pérez-Bravo / ORC ID: 0000-0002-1310-0145, Researcher ID Thomson: N-3319-2018, CVU CONACYT ID: 501992

ID $2^{\text {nd }}$ Coauthor: Francisco Javier, Arellano-Rocha / ORC ID: 0000-0001-8530-9936, Researcher ID Thomson: X-21202018, CVU CONACYT ID: 953180

ID $3^{\text {st }}$ Coauthor: Jorge Gabriel, Villarreal-Alcalde / ORC ID: 0000-0003-3101-3683, Researcher ID Thomson: X-32222018, CVU CONACYT ID: 999686

DOI: $10.35429 /$ EJRS.2019.9.5.23.33

Received August 24, 2019; Accepted November 29, 2019

\section{Abstract}

The video game represents a great opportunity for the student community to refresh and diversify the activities and tasks inherent in teaching and learning, taking advantage of the immersive, interactive and multimedia features offered by videogames to improve the use of university students. The objective of this work is to identify and make known the characteristic elements that certain videogames must have so that they can be used in university work, since there are endless options in the market whose general purpose is to entertain, however, you can highlight certain elements within them that can support the teaching practice. The present investigation methodology is of the theoretical type with descriptive study through which it is tried to offer validity, utility and universality to the phenomenon of study. The contribution is led towards the improvement of certain university educational procedures by identifying certain distinguishing parameters in video games that provide certainty that they could be used as support to improve the university teaching practice.

\begin{abstract}
Resumen
El videojuego representa una gran oportunidad para la comunidad estudiantil de refrescar y diversificar las actividades y tareas inherentes a la enseñanza-aprendizaje, aprovechando las características de inmersión, interactividad y multimedios que ofrecen los videojuegos para mejorar el aprovechamiento de los estudiantes universitarios. El objetivo de este trabajo es el identificar y dar a conocer los elementos característicos que deben tener ciertos videojuegos para que puedan ser utilizados en la labor universitaria, ya que existen un sinfín de opciones en el mercado cuyo propósito general es el de entretener, sin embargo, se pueden destacar ciertos elementos dentro de los mismos que pueden apoyar la práctica docente. La metodología de la presente investigación es del tipo teórica con estudio descriptivo a través de los cuales se pretende brindar vigencia, utilidad y universalidad al fenómeno de estudio. La contribución esta conducida hacía la mejora de ciertos procedimientos educativos universitarios mediante la identificación de ciertos parámetros distinguibles en los videojuegos que brinden certeza que los mismos podrían utilizarse como apoyo para mejorar la práctica docente universitaria.
\end{abstract}

Videojuego, Herramienta, Universitaria

Citation: GONZÁLEZ-NERI, Aarón Iván, PÉREZ-BRAVO, Julia, ARELLANO-ROCHA, Francisco Javier and VILLARREAL-ALCALDE, Jorge Gabriel. Elements to consider the video game as a support tool in the university classroom. ECORFAN Journal-Republic of El Salvador. 2019. 5-9: 23-33.

$\dagger$ Researcher contributing first author. 


\section{Introduction}

The current context assumes that university educational institutions must take care of promoting the adaptation and use of more and better instructional and training tools for their students to provide better professionals to society. In addition to the above, it is well known that information and communication technologies are relevant to improve any process, and in this case, in education the videogame tool is addressed as university support; and it is approached from the perspective of identifying the characteristics and types of video games that can best be directed towards the achievement of significant learning in the university classroom.

It is important that if an out-of-traditional tool is to be used for the teaching-learning process, it can be tested and verified under certain analysis and observation parameters, in order to determine if it is feasible to use it also identifying how it could be more efficient.

Although there are teachers in educational institutions that carry out learning activities using some video games, it is necessary to reflect on the characteristics and knowledge of the video game universe to better identify which are the parameters to be distinguished from them that increase the possibility of designing learning activities based on video games that contribute to improve the significant learning of university students.

The problem that is sought to be solved is to distinguish types and characteristics of video games that support university educational work, in order to reduce the list of the existing video game universe so that teachers have greater certainty of which can support them and which do not. The work is integrated by justification, problem, hypothesis, objectives, theoretical framework, research methodology, discussion and analysis, results and conclusions.

\section{Justification}

It is found that, as in any field of life, teachers must find ways to reinvent their work, to increase their chances of encouraging their students to be interested and work to improve their knowledge and skills to take on future challenges aimed primarily at the workplace.
Video games represent a very important possibility for the promotion of the educational practice of the new times, where the use of information and communication technologies have transformed the way of understanding education, changing from being unidirectional to being multidirectional and moving books away. of text of the center of the educational scene. (Batalla, 2017). The video games have multimedia and interaction elements that test the coordination, skill and mental ability of the video gamers, therefore, it is visualized that thanks to these elements it is possible to develop proposals for educational situations based on video games that help the actors of the game University educational process to increase its efficiency, of course, as long as these video games have the necessary and sufficient characteristics to provide that possibility, elements that are sought to be discovered in this work.

\section{Problem}

The problem is focused on the identification of the characteristics of video games that can really be used in the university educational field. It is therefore necessary to also identify the nature of most video games, which are created to meet entertainment needs for gamers, and commercial and market needs for developers. However, you can find some types of video games whose objective of being created is to generate learning in its users such as "serious games", which for Diaz (2016), are those games that are used to educate, train and inform.

It is also the reason for this work to highlight that even though most video games are made to entertain, they should not automatically be discarded for use in university education, since they can still contain elements that can be used to generate an analysis, a situation, a decision or some reflection that helps the teaching-learning process.

\section{Hypothesis}

The hypothesis of this work is determined by the premise of determining the distinguishable elements of a videogame that allows us to identify it as a potential use for university education. Therefore it is as follows: 
In the video game distinguishable elements of interactivity, plot, game mechanics, history, context, music, type or any other are identified that allow them to be identified as usable to generate from them learning activities applicable to meaningful learning in the university classroom.

\section{Objectives}

General objective.

Determine what are the elements to consider so that a video game can be used as a tool to improve meaningful learning in the university classroom.

\section{Specific objectives.}

- Specify what types of video games can contribute to university teaching practice.

- Specify which elements of the characteristics of a video game are distinguishable to highlight in a possible learning activity design.

- Knowing better or in greater depth the structure and elements of a videogame to propose in turn better and more accurate learning activities.

\section{Theoretical framework}

The videogame

The video game for more than three decades has become part of the vocabulary of people, understanding this, according to the Royal Spanish Academy (2019) as: "an electronic game that is displayed on a screen" and "electronic device that allows, using appropriate controls, simulate games on the screens of a television, a computer or other electronic device ". The simple definition of videogame proposed by the Royal Spanish Academy is somewhat limited for what is proposed in this work, which is why the proposal by Burgun (2012, cit. In Benítez, 2018) is retaken who determined that: "a videogame is a system of rules where participants compete making ambitious decisions, in addition to the fact that the opponents must not necessarily be human, since one can be a person while the other player can be the computer using artificial intelligence".
To pay with the definitions you can share the proposal of Jiménez and Araya (2010, cit. In Córdoba and Ospina, 2019) for whom a video game is: "a computer program in which the user or player maintains an interaction through images that appear on a device that has a screen that can vary in size". It is necessary to emphasize that to talk about videogames is to talk about a set of very complex elements, ranging from the use of a hardware platform that allows them to be launched, to a variety of software layers, where rules, methods, environments, characters are found, very specific actions, tools and mechanics, where the user interacts with them, using any type of command, screen or movement, to meet certain objectives that arise within the aforementioned setting.

Types and characteristics of video games.

There are several ways to classify video games, since there are many of them and the way to approach the classification depends a lot on the approach that needs to be analyzed, for example, there is a classification according to the type of content that the videogame includes, according to Videogames101 (2019) medium specialized in the subject; This classification is regulated by international organizations where the standard that applies to most of the world, including Mexico, is the Entertainment Software Classification Board also known by its acronym in English as ESRB. The mentioned classification is divided into the following elements:

- Ranking Categories: These suggest an appropriate age for each game. (Pending Classification, Young Children, All Ages, All 10+, Teens, Older 17 and Adults Only)

- Content descriptors: Elements that argue the possible classification and that may be of interest, for example: "Strong Language" that implies the use of high-sounding words or "Violence" which means that in the game you can find conflicts and / or aggressions.

- Interactive elements: Determines whether user information can be shared with third parties and / or the ability to interact with other users. 
For egamers (2018), also specialized in videogames, videogames are classified by type, in this case determined by the genres to which their characteristics respond, and these are:

- Action: They put the player in situations of passing obstacles, defeating enemies and testing reflexes and reaction.

- Platform: Move forward and dodge obstacles, avoiding falling into gaps.

- Fight: End the enemy's health points by using punches, kicks, grabs and / or weapons.

- Fight progression or Beat 'em up: Make your way through waves of enemies by hitting or kicking.

- Shooter: Make your way through waves of enemies using gunshots mainly.

- Hack and slash: Advance between waves of enemies by using weapons, swords, spears or any other, mainly using keystrokes of a button repeatedly.

- Arcade: Fast action characterized by simple and repetitive movements.

- Adventure: Explore places and discover important elements for plot development.

- RPG: RPG, characterized by improving the skills of the characters through battles and missions.

- Sports: Sports-inspired games.

- Strategy: Management of huge numbers of characters and resources. Intelligence and ability must be used to manage them in the best way.

- Simulation: Video games that try to recreate some activity or situation as faithful as possible.

- Musicals: Those who place the main elements so that the player can imitate playing a song with a simulated instrument, dancing a melody or singing.

- Party game: Amuse family and / or friends with activities and challenges where anyone can participate.
- Of cards: Adaptations of card games under virtual environments.

- Educational: Its main objective is to leave some learning in the players.

Likewise, Cuenca (2011) classifies video games according to their contents in a very similar way to egamers, as follows: shooters, simulators, role, platform, adventure, action, survival horror, strategy, musicals, party, sports, racing, sandbox, multiplayer and online, where multiplayer and online apply for simultaneous interactions of several players at the same time, where the difference lies only in itself the interaction is local or in the same place, or through the Internet; The racing ones can be included in the sports, the survival horror are survival with dyes of terror and the sandboxes do not have a development line, they simply give freedom to perform what the player wants without limits of times, missions, activities or resources.

\section{Videogame Features}

Just as there can be different approaches when classifying video games, so is it to determine their characteristics. For this work the ideas of Cáceres and González are shared, which are detailed below.

Cáceres (2013) who conducted a study of the characteristics of videogames and their possibilities in education, shares his analysis of four characteristics of videogames that he considers distinguishable which are: rules, goals and objectives, narrative and fantasy.

The rules represent the limits, that is, the determination of what can or cannot be done, as well as the conditions to meet the objectives of the game.

The objectives and goals are what you want to reach, will be determined by the specification of certain events or situations that must be done and achieved in the game. If you get it, you win, but you lose.

The narrative according to Simons (2007, cit. In Cáceres, 2013) is the core of the video game, where are the explanations and understandings for the interpretation of identities and stories. 
Through the narrative, the development of events that happen as the game progresses is shaped.

Fantasy is an element that most videogames contain, if not all, since it implies the presentation of a world that does not exist in real life, is a series of contextualized elements that are under a virtual environment. In these worlds there are certain rules and conditions that can be adjusted to reality or not.

Now, González's ideas have to do with videogame characteristics that are related rather, with their design, but which, however, is interesting to review some of them for purposes of this work.

There is a very important element in videogame design, this is the design document. Within the design document according to González (2011) you must find all the information related to it, which allows you to understand and land all the edges of the project to create a video game. It is a guide that guides developers by determining the elements that should be considered to structure the video game. These elements are specified below and briefly described:

- Project description: Explanation of what the project is about, what benefits and positive characteristics it has.

- Key points of sale: Describe how important or relevant the game is. That innovation will differentiate it from others or put it in a place of greater interest.

- Technology: Specify which graphics engine you will use (software to create it) and on which platform you will run (hardware).

- Storyline: Summary of the script, where you can perfectly distinguish where the story and plot of the game is directed.

- Game modes: Explanation of the different ways in which the game will be assumed. Whether for single player, online multiplayer, etc.

- Game options: How to configure the controls, buttons or general settings such as the screen or difficulty level.
- Game mechanics: How the video game is going to be played. Specify how the movement of the characters will be, what events and objects will react and in what way. In general, it implies how the characters will behave regarding the movement and interaction with the entire virtual environment to which they are subject.

- Environments: Specify scenarios and subscenarios, as well as detail their characteristics and possibilities of interaction with them.

- Items: Define and describe which ones and what they are for are the objects and aids that the videogame will offer to the characters.

- Characters: Description of the appearance, character and roles that the characters will have.

- Vehicles: Physical description and characteristics of being usable, destructible or not, and where to find them among others.

- Cameras: Definition of where the video player's viewing angle will be with respect to the characters or the action, as well as the possible interaction and movement through the controls.

- Artificial Intelligence: Behavior of noncontrolling characters by the gamer.

- Kinematics: Function and characteristics of illustrative videos that support improving the understanding of the plot.

- Audio and music: Determine how the video game's sound setting will be.

- Walkthrough: Step by step description of what needs to be done to finish a video game.

- Fun ends and elements: Determine conditional elements that allow the gamer to find different alternatives and conclusions for the same story.

- Ideas and references: Motivational or inspirational elements that were presented to determine the current characteristics of the characters, settings, etc. 
It is important to emphasize that the videogame catalog is so extensive that some games can fall into several categories and / or contain several of the features mentioned above or simply have only a few. This is mainly due to their nature, that is, a video game resulting from a Halo or God of War blockbuster will have many more elements than a puzzle-type smarphone videogame for example.

The understanding of the characteristics and representative elements that a videogame can contain can bring the teacher closer to understand better what scope and possibilities it can offer for use in a classroom. learning.

University classroom and significant

The university classroom refers to the physical or virtual space, where processes and activities related to learning of a subject related to a curricular plan belonging to a specific degree are carried out, that is, it refers to the actions and measures taken for the development of higher education students.

Higher education has very important challenges and obligations in today's times, which is why those responsible for designing and carrying out learning activities must meet certain requirements and expectations regarding the demands and contexts in which they live today.

Therefore, the situation arises to identify what are the learning goals that are sought in higher education. For Ramsdem (2007, cit. In Guzmán, 2011) they are classified in:

- The abstract, generic and personal development.

- Those referring to the domain of disciplinary knowledge including particular skills and techniques that distinguish each profession.

The first point above can be summed up in the following premises: teaching students to analyze ideas and issues critically, developing intellectual and thinking skills in students, as well as teaching students to understand principles and generalizations. The second point is summarized in analyzing, understanding, appreciating the meaning or interpreting. (Guzmán, 2011)
In turn, to pay for the previous premises, it is shared that for Hierro (1994, cit. In Bautista, 2008), higher professional education pursues two basic objectives, which are: to meet the needs of highly qualified personnel required by the state and train intellectuals that preserve, disseminate and establish a new culture. In any case, it is considered that, to achieve the goals of both learning and social impact, it is necessary to address the concept of meaningful learning.

The concept of meaningful learning can be approached with the ideas of Ausubel, considered an institution in the subject. For Ausubel (1976, cit. In Rodriguez, 2004), meaningful learning is: "the process according to which a new knowledge or information is related to the cognitive structure of the one who learns in a non-arbitrary and substantive or non-literal way. This interaction with the cognitive structure does not occur considering it as a whole, but with relevant aspects present in it, which are called subsumers or anchor ideas".

The foregoing determines that significant learning is based on a constructivist paradigm because knowledge is built on previous knowledge and also that the figure of the student becomes more protagonist, since it is the same student who reflects on his learning process interacting cognitively in all directions and at your own pace. Meaningful learning is also the one that implies that the student finds and identifies perfectly in the knowledge that he acquires, a well-defined purpose, that he knows what it is for and how to apply it correctly in different activities, as well as in different levels of significance or value that can be given to that same knowledge, as stated by Carranza (2017) based on Coll's studies. Carranza (2017) himself presents a summary of the levels of significance of Coll, who names them learning dimensions, thus defining them:

- Motivation: Real commitment to the learning process by the student.

- Understanding: Relationships between new content and prior knowledge are established.

- Functionality: That the knowledge acquired can be effectively used.

- Active participation: the study, analysis, discussion and preparation of the information received. 
- The relationship with real life: Application or use of the information received to solve possible real problems.

These learning dimensions range from psychological aspects, mental efforts and the union of knowledge with real life. Now, the vision of Alvarado, Munguía and Castellanos (2017) is shared, who carried out a study of significant learning in higher education teaching, where the following statement is especially rescued: "... the mission of higher education is not so much to teach to the student a multitude of knowledge that belong to very specialized fields, but, above all, to learn to learn, to ensure that the student comes to acquire an intellectual autonomy.

Give rise to stimulate learning in the classroom, understanding this as meaningful learning." Thus, and according to the previous information, it can be noted that the University from higher education is requiring the granting of its students with significant learning, of course, through its teachers, in order to meet the particular goals and generals to which it is due.

\section{Learning activities.}

To achieve the meaningful learning addressed in the previous section, it is necessary to make a link between the teacher and the student, this link may well be materialized with the learning activities, which, through their correct use, guarantee student learning.Learning activities can be identified as actions and / or resources that serve to learn or acquire knowledge of a particular subject or discipline. (Penzo, 2010).

Likewise, the Ministry of Education, Science and Research of the region of Murcia in Spain, through the General Directorate of Educational Promotion and Innovation (s / f), publishes that the activities are put into practice of the content previously selected through procedures, activities or exercises that must be designed, which may contain pedagogical, psychological elements (age, motivation, interaction) and / or elements of planning and management of classroom activities.
In turn, Taba (1974, cit. In Delgadillo, 2005) points out that learning activities can also be understood as learning experiences that must fulfill a function to promote knowledge and respond to the maturity stages of the subjects, and that should be raised according to the following domains: reasoning ability, inductive reasoning activities, deductive ability activities, visospatial relationship activities and verbal abilities. However, learning activities can be linked to videogames through the work of Montero (2010), who states that to work with video games contemplated in learning activities is required: set the objectives, find and choose the tools you want to use, schedule the intervention, develop the activity, evaluate and share the activity. It can be noted that the use of well-established learning activities and aimed perfectly at the learning objectives, as well as the identification of the cognitive abilities of the subjects who are going to interact with them, implies the practice or exercise required to achieve meaningful learning.

\section{Research methodology}

The methodology of the present investigation is of the theoretical type with descriptive study through which it is intended to give validity, usefulness and universality to the phenomenon of study.

The above is framed under the premise of the literature review related to the phenomenon of study to find validity or rejection of the hypothesis raised, as well as address the issues necessary to achieve the objectives of the research.

\section{Discussion and Analysis}

It is necessary to deepen the relationship between the characteristics that make up a video game, the learning activities and the university classroom to be able to decide if the identification of the characteristics of the video game can help a possible formulation and design of activities that contribute to the achievement of significant learning in the university classroom.

As for what is seen in the literature reviewed in relation to the characteristics of videogames, it can be highlighted that there are classifications according to the content, according to the type of mechanics and design, if they are large productions or if they are simple low-resource videogames.

GONZÁLEZ-NERI, Aarón Iván, PÉREZ-BRAVO, Julia, ARELLANOROCHA, Francisco Javier and VILLARREAL-ALCALDE, Jorge Gabriel. Elements to consider the video game as a support tool in the university classroom. ECORFAN Journal-Republic of El Salvador. 2019 
While most try to meet the objective of entertaining, there are also educational video games, serious games and simulators that have features completely focused on learning.

Thus it is also found that video games have very distinguishable elements within their general structure, you can mention the game mechanics, which is the way or way in which the user controls the movements of the character and how he reacts to them, the history, which is the description of the sequence of actions that the character or characters perform during the development of the plot and how they affect the surrounding environment; and music, which implies the sound sequences that accompany the moments that are experienced in the development of the video game.

Related to the aspect of university teaching-learning, it was identified that universities need to meet the need of society to generate qualified personnel, who can apply their knowledge in organizations, as well as disseminate culture. Some types of video games can contribute in this regard, such as simulators or some action games that tell history and explain how some past and present societies and cultures work or functioned.

In the studies of Gamo (2015, cit. In Martínez, García and López, 2019) it is shared that he managed to identify that the development of virtual laboratory platforms as a complement to the classroom leads to the development of knowledge, socio-communication and collaboration that students should acquire.

Now addressing the theme of the learning activities reviewed in the bibliography, we can distinguish that they imply practical exercise, they must be oriented towards a certain student profile, and they must reflect some pedagogical reflection in their design so that they can really serve to generate meaningful learning.

Therefore, it seems important to share the studies of Montero (2010) who assures that to select a videogame as a tool for learning, it must take into account: the group to which it is addressed, the objectives that are intended with the intervention through video games, the sequence methodological method by which it will be used and the technical and economic resources available to them.
In this last point it would be added that the Ludologos work group (s / f, cit. In Montero, 2010) also chooses to prioritize videogames with the following characteristics: low cost or free, discontinued and online. The justification of the above is in the premise that the selected videogames do not require large computer requirements so that they can be used with the means available in most educational centers, as well as that the configuration and commissioning is very simple and basic for both teachers and students.

Under the same vision of Montero (2010), a series of guidelines to be followed for the selection of video games is shared according to the methodological sequence that is required to be used, and these are: as an introduction to a topic, within a sequence of learning, as a synthesis of contents, in specific moments and for the pure pleasure of playing. In the end, the same author states that it is the task of the educator to define their activities, try different types of games, different times, use different methodologies and record the process, regardless of which video game is selected.

Regarding the revised information on research related to the use of video games in the university classroom, the study by Borro (2015) is shared, who carried out a work where educational simulations with game strategy are systematized in the medical field. This work is interesting to highlight the following aspects related to the characteristics of the video game that in the study considered very relevant for its efficiency and are listed below:

- Script: The player is placed in a context, the objectives, the rules and the role he has are presented.

- Logic: The game should encourage player decision making.

- Feedback: Feedback is essential during the game because in this way you learn while playing and retaining information.

- Ludification: Inclusion of game elements such as lives, time or bonus, to increase motivation.

- Difficulty adjustment: To maintain a balance between design elements and complexity over time and the achievement of objectives. 
Apart from the elements mentioned above, it should be noted that Borro (2015) specifies in his conclusions that students find motivating and with high acceptance the use of medical simulators, since the learning they obtain is real. It should also be mentioned that the simulators used were specially developed to be educational, and although the author concludes that they are not too expensive, it should be specified that each University has its own characteristics and budgets, and that in the end, that may be relative.

To conclude with the analysis and discussion section, the work of Urquidi and Calabor (2014) is addressed, who conducted a study of the factors that determine the pedagogical efficiency of simulation games during a university course in the business area. Among its conclusions it is found that students who took the course using simulations valued two major factors, the first, the realism of the simulation, the second, the immediate feedback. It should be noted that it was also found that the ease of use is not so significant for the students, perhaps motivated to the fact that most of the respondents were digital natives who use video games normally.

\section{Results}

Taking up the hypothesis that is: In the video game distinguishable elements of interactivity, argument, game mechanics, history, context, music, type or any other are identified that allow them to be identified as usable to generate from them learning activities applicable to learning significant in the university classroom; It can be affirmed according to the conclusions of the documentation addressed that is feasible. The hypothesis is not accepted or rejected because in general there is a great diversity of videogames and typecasting some combinations of characteristics of some types of them as determinants to be used in the university classroom would be very unfair.

It must be distinguished that while some features of video games such as game mechanics, history or type may work for a particular learning situation, they do not necessarily work well for entertainment and / or vice versa. Each video game can be approached or designed to entertain, motivate or teach depending on the characteristics offered, but also the objectives for which it is required.
Regarding the general objective, it can be shared that there are characteristic elements of video games that contribute to university learning. Placing the focus on the types of video games that mostly contribute to meaningful university learning are serius-games and simulators, since they are designed and designed to generate user learning, first, and secondary entertainment appears and / or fun.

Another important element to highlight is that videogames that are selected to be used as support for learning are online, with few computer requirements or even abandonware. Large productions are not easily affordable and implementable in schools of any level. Likewise, some elements were found that were not contemplated in the hypothesis or in the objectives, these are the level of realism and immediate feedback in reference to what a videogame includes to help generate significant learning, and in terms of design, it helps to define a script, the logic, again the feedback, the gamification and the adjustment of difficulty. In turn, in terms of specific objectives, it is denoted that in order to design learning activities, the characteristics of the video game to occupy do not seem to really matter. However, if certain recommendations are found. The main weight of the design of learning activities lies with the teacher. It must be soaked in the context in which it works, the Educational Institution, the type of students and previous university training they may have, as well as the technological tools available for the activities. You must define specific and achievable objectives, as well as establish a methodological sequence and a plan to follow for the same activity.

It should be noted that it is very important that the teacher who designs, must use and practice with different video games, scenarios and moments, record the events happened and reflect on this, all this, before, during and after the application of the same activity. It is also necessary to verify that video games are suitable for certain areas of knowledge, if the mechanics are sound and if the nature of the video game does not contradict the basic ethical and moral principles, both of the teacher, of the students and of the same educational institution, since as Ortega and Fuentes (2009) conclude in their study of video games and violence, that violent video games have little or no ethical-educational value. 


\section{Conclusions}

There are elements that are usually very attractive for a video game to sell well, such as graphic detail or music, however, for education it may not be the same way, since the goal of education is learning, while the games pretend to entertain and bring unforgettable experiences to its users, regardless of whether or not they learned something in the process.

It is shared that there are characteristic elements of video games that can support in university education, mainly the type of video games, in this case they are of the serius games or simulators type. It is also recommended that they are not large productions to opt for online games, freeware (free license) or abandonware (discontinued software). Thus it was also discovered that it is important that video games that support meaningful university learning reflect a high level of realism, immediate feedback and that they have the basic elements of the design of a videogame, as an adequate script, logic for decision making, ludification that includes elements such as lives and items, as well as the adjustable difficulty level.

Finally it is clarified that regardless of the video game, it is the work of the teacher who designs learning activities based on video games consider the university educational context, the objectives, moments, methodology, as well as registration and reflection to perform that work, since there is no specificity clear that indicates if a set of features of a video game increase or decrease their chances of being used in education, although what can be done is to reduce the list, to the types and characteristics mentioned above and especially to discard violent games, that it is proven that they do not conform to the ethical and moral principles of the actors of the educational process or to those of the institutions.

\section{References}

Alvarado, J., García, M. y Castellanos L. (2017). Aprendizaje Significativo en la docencia de la educación superior. Xicua. Boletín científico de la Escuela Superior de Tlahuelilpan. Volumen 5. No. 9. Enero 2007. Recuperado el 26 de julio de 2019 de: https://www.uaeh.edu.mx/scige/boletin/tlahuelil pan/n9/e1.htm006C
Batalla, J. (2017). Por qué los videojuegos son claves en la nueva educación. Recuperado el 09 de Julio de 2017 de: https://www.infobae.com/tendencias/innovacio n/2017/06/18/por-que-los-videojuegos-sonclaves-en-la-nueva-educacion/

Bautista, S. (2008). Habilidades de dirección del servidor público en la facultad de estudios superiores Acatlán de la Universidad Nacional Autónoma de México. (Tésis de Doctorado). Universidad Nacional Autónoma de México. México. Recuperado el 26 de julio de 2019 de: http://www.eumed.net/tesisdoctorales/2008/sdba/sdba.zip

Benitez, V. (2018). Los videojuegos como herramienta de aprendizaje en México. Recuperado el 22 de julio de 2018 de: http://catarina.udlap.mx/u_dl_a/tales/document os/lnd/benitez_salinas_ve/etd_3021080218481. pdf

Borro, B. (2015). Sistematización del desarrollo de simulaciones educativas con estrategia de juego en el campo médico. (Tesis doctoral). Universidad Complutense de Madrid. Madrid. España.

Cáceres, R. (2013). Acercamiento a las características de los videojuegos y sus beneficios en el aprendizaje. Recuperado el 23 de julio de 2019 de: https://www.academia.edu/6187165/Acercamie nto_a_las_caracter\%C3\%ADsticas_de_los_vid eojuegos_y_sus_beneficios_en_el_aprendizaje

Carranza, M. (2017). Enseñanza y aprendizaje significativo en una modalidad mixta: percepciones de docentes y estudiantes. Recuperado el 26 de julio de 2019 de: http://www.scielo.org.mx/scielo.php?script=sci _arttext\&pid=S2007-

$\overline{7} 4672017000200898 \& \operatorname{lng}=\mathrm{es} \& \mathrm{nrm}=$ iso

Córdova, M. y Ospina, J. (2019). Los videojuegos en el proceso de aprendizaje de los niños de preescolar. Revista Interamericana de Investigación, Educación y Pedagogía, RIIEP, 12(2), 113-138. Recuperado el 2 de septiembre de 2019 de: https://revistas.usantotomas.edu.co/index.php/ri iep/article/view/5010/4904 
Cuenca, D. (2011). Usos y gratificaciones de los videojuegos en la Ciudad de México: el caso de las Arcadias, Tesis de Licenciatura en Comunicación y Cultura. Universidad Autónoma de la Ciudad de México, México.

Delgadillo, R. (2005). Las actividades de aprendizaje como estrategia de enseñanza. El caso de tres cursos en línea. Recuperado el 1 de agosto de 2019 de: http://www.revistadecires.cepe.unam.mx/articul os/art12-4.pdf

Díaz, F. (2016). Los juegos serios y su potencial como dispositivos educativos. Recuperado el 09 de Julio de 2017 de: http://www.eduforics.com/es/los-juegos-seriosy-su-potencial-como-dispositivos-educativos/

Dirección General de Promoción Educativa e Innovación. (2010). Metodología y actividades de aula en la enseñanza-aprendizaje de EL2. Recuperado el 15 de agosto de 2019 de: http://servicios.educarm.es/templates/portal/fich eros/websDinamicas/93/metodologiatema.pdf

Egamers, (2018). Tipos de videojuegos: Principales géneros que todo gamer debe conocer. Recuperado el 23 de julio de 2019 de: https://www.egamers.com/2018/08/26/tipos-devideojuegos-principales-generos-que-todogamer-debe-conocer/

González, D. (2011). Diseño de videojuegos. Da forma a tus sueños. México: Editorial Alfaomega.

Guzmán, J. (2011). La calidad de la enseñanza en educación superior ¿Qué es una buena enseñanza en este nivel educativo? Recuperado el 26 de julio de 2019 de: http://www.scielo.org.mx/scielo.php?script=sci _arttext\&pid=S0185-26982011000500012

Martínez, M., García, M. y López, L. (2019). MATHVR-UANL en cálculo de varias variables. Revista de Experiencias Didácticas e Investigación en Educación Matemática, 1(1), 76-79. Recuperado el 2 de septiembre de 2019 de:

http://revistas.uaz.edu.mx/index.php/REDIEM/ article/view/576/523

Montero, E. (coord.) (2010). Aprendiendo con videojuegos. Jugar es pensar dos veces. Madrid: Ministerio de Educación y Narcea, S.A. de Ediciones.
Ortega, J. y Fuentes, J. (2009). Los videojuegos violentos y su incidencia en la educación en valores: Los centros educativos como agencias de cultura de paz. Revista Educatio Siglo XXI, Vol. 27.2. 2009. pp. 119-146. Recuperado el 28 de agosto de 2019 de: http://redined.mecd.gob.es/xmlui/bitstream/han dle/11162/87090/01820103010569.pdf?sequenc $\mathrm{e}=1$

Penzo, W. (Coord.) (2010). Guía para la elaboración de las actividades de aprendizaje. Cuadernos de docencia universitaria. Barcelona: ICE y Ediciones OCTAEDRO, S.L. Recuperado el 14 de agosto de 2019 de: http://www.ub.edu/ice/sites/default/files/docs/q $\mathrm{du} / 15$ cuaderno.pdf

Real Academia Española, (2019). Diccionario de la lengua española. Actualización 2018. Recuperado el 22 de julio de 2019 de: https://dle.rae.es/?id=bmnbNU7

Rodríguez, M. (2004). La teoría del aprendizaje significativo. Recuperado el 26 de julio de 2019 de: http://cmc.ihmc.us/papers/cmc2004-290.pdf

Urquidi, A. y Calabor, M. (2014). Aprendizaje a través de juegos de simulación: un estudio de los factores que determinan su eficacia pedagógica. EDUTEC. Revista electrónica de Tecnología Educativa. Número 47. Abril 2014. Recuperado el 19 de agosto de 2019 de: www.edutec.es/revista/index.php/edutece/article/download/75/pdf_6

Videojuegos101, (2019). ¿Sabías que los videojuegos son clasificados de acuerdo al tipo de contenido incluído? Recuperado el 23 de julio de 2019 de:

https://videojuegos101.com/aulavirtual/videoju egos/clasificacionjuegos/.

GONZÁLEZ-NERI, Aarón Iván, PÉREZ-BRAVO, Julia, ARELLANOROCHA, Francisco Javier and VILLARREAL-ALCALDE, Jorge Gabriel. Elements to consider the video game as a support tool in the university classroom. ECORFAN Journal-Republic of El Salvador. 2019 